\section{Seasonal Change of Nitrate and Oxalate Concentration in Relation to the Growth Rate of Spinach Cultivars}

\author{
Aiko Kaminishi and Nobuhiro Kita ${ }^{1}$ \\ Division of Vegetable and Crop Science, Kanagawa Agricultural Technology \\ Center, 1617 Kamikisawa, Hiratsuka, Kanagawa 259-1204, Japan
}

Additional index words. cultivation season, frequency distribution, rank correlation, bolting rate

\begin{abstract}
Reduction of nitrate and oxalate content in spinach (Spinacia oleracea L.) has become the major concern in terms of their toxicity to human health. The primary objectives of this study were 1) to determine the seasonal change in nitrate and oxalate concentrations and 2) to elucidate the relationship between growth rate and concentration of nitrate and oxalate in spinach. In a replicated field experiment in Hiratsuka, Japan, the authors grew 182 cultivars of spinach over four growing seasons (winter, spring, summer, and fall) under the nitrogen application rate of $100 \mathrm{~kg} \mathrm{~N} \cdot \mathrm{ha}^{-1}$. The average number of days required for harvest was the shortest in summer (32.7 days) and was longest in the winter (85.7 days). Mean nitrate concentration in spinach was significantly low in the winter $\left(3797 \mathrm{mg} \cdot \mathrm{kg}^{-1}\right.$ fresh weight) compared with the other three seasons (4122-4328 mg $\mathrm{kg}^{-1}$ fresh weight) in which no significant differences were found in mean nitrate levels. In contrast, oxalate concentrations showed a distinct seasonal variation, being the lowest in the fall $\left(6149 \mathrm{mg} \cdot \mathrm{kg}^{-1}\right.$ fresh weight), followed by the summer (7525 $\mathrm{mg} \cdot \mathrm{kg}^{-1}$ fresh weight) and the spring $\left(8903 \mathrm{mg} \cdot \mathrm{kg}^{-1}\right.$ fresh weight), and was the highest in the winter $\left(10,929 \mathrm{mg} \cdot \mathrm{kg}^{-1}\right.$ fresh weight $)$. Relative nitrate concentration showed a moderate negative correlation with relative days required for harvest $(r=$ $0.411, P<0.001)$, whereas relative oxalate concentration showed a strong positive correlation with relative days required for harvest $(r=0.566, P<0.001)$. Accordingly, a moderate negative correlation $(r=0.325, P<0.001)$ was detected between nitrate and oxalate concentrations. Moreover, fast-growing cultivars contained higher nitrate and lower oxalate, whereas slow-growing cultivars contained lower nitrate and higher oxalate. These results indicate that the growth rate primarily accounts for the nitrate and oxalate concentration in spinach, and nitrate and oxalate might play a counterrole to each other.
\end{abstract}

Spinach (Spinacia oleracea L.) is one of the most important leafy vegetables for vitamins and minerals, and is grown worldwide for both fresh and processing use on about 827,059 ha with 13 million tons produced in 2005 (Food and Agriculture Organization, 2005). China accounts for more than $85 \%$ of total production followed by the United States (3.2\%), Japan (2.3\%), and Turkey (1.7\%). However, spinach also contains nitrate and a relatively large amount of oxalate, both of which affect not only the taste but also human health. Nitrate is reduced to nitrite in the gastrointestinal tract and, upon absorption into the bloodstream, nitrite may cause oxidation of hemoglobin, resulting in methemoglobinemia (Gangolli et al., 1994;

Received for publication 17 June 2006. Accepted for publication 31 July 2006.

This paper was supported in part by a research project for utilizing advanced technologies in agriculture, forestry, and fisheries.

We thank Yoko Takahashi and Makoto Yoshida for their technical support during this research and Joji Muramoto, Akira Kagawa, and Takeo Kitaura for their valuable suggestions.

${ }^{1}$ To whom reprint requests should be addressed; e-mail kita.ihgr@pref.kanagawa.jp
World Health Organization, 1995) and formation of carcinogenic nitrosamines (Walker, 1990). Oxalate acts as an antinutritive, calcium-binding component, sometimes triggering kidney stones (Libert and Franceschi, 1987; Massey et al., 1993). Thus, reduction of nitrate and oxalate content in spinach is the major concern in terms of the potential health hazards. Actually, most European countries regulate the nitrate content in vegetables (including spinach), and other countries such as the United States, Korea, and Japan have pointed out the importance of this problem (Muramoto, 1999). However no such standards have been set for oxalate concentration.

The growth pattern of spinach differs among cultivars as a result of the unique response of each cultivar to photoperiod and temperature. Nitrate and oxalate concentrations in spinach have been extensively studied in relation to growth habits and have been shown to differ, depending on tissue, nutrient amount and their balance in soil, light intensities, growing season, and cultivars (Barker, 1975; Cantliffe, 1972a,c, 1973; Chung et al., 2003; Lorenz, 1978; Muramoto, 1999; Regan et al., 1968). Differences of nitrate and oxalate concentrations in petiole and leaf blade are distinct; nitrate concentration is high in petiole and low in leaf blade, whereas oxalate concentration is low in petiole and high in leaf blade (Elia et al., 1998; Maynard et al., 1976). Although environmental factors affecting oxalate concentration have not been studied extensively, nitrate concentration is known to be strongly influenced by the amount of $\mathrm{N}$ in soil, the form in which the $\mathrm{N}$ is applied, the time of application, the age of plants, the quantity and quality of soil organic matter, soil $\mathrm{pH}$, rainfall, temperature, and other environmental conditions (Breimer, 1982; Muramoto, 1999). Muramoto (1999) reported that average nitrate concentration of spinach grown in the United States was $2170 \mathrm{mg} \cdot \mathrm{kg}^{-1}$ fresh weight with a variation from 130 to 4100 $\mathrm{mg} \cdot \mathrm{kg}^{-1}$ fresh weight depending on cultivation practices and cultivars used. In Korea, the average was $4259 \mathrm{mg} \cdot \mathrm{kg}^{-1}$ fresh weight, with ranges from 427 to $7439 \mathrm{mg} \cdot \mathrm{kg}^{-1}$ fresh weight in the winter and 195 and 7793 $\mathrm{mg} \cdot \mathrm{kg}^{-1}$ fresh weight in the summer (Chung et al., 2003). As for the cultivars, differences of nitrate concentration among cultivars were noticed depending on the leaf types such as savoyed, semisavoyed, and smooth-leaf types, but the results obtained were not always consistent (Barker et al., 1974; Muramoto, 1999; Olday et al., 1976). This seems to be because most experiments were performed using a limited number of spinach cultivars in a specific growing season under different cultural practices. There are more than 400 spinach cultivars (Pandy and Kalloo, 1993) that have variable genetic backgrounds, especially with regard to their response to temperature and day length.

The objectives of the current study were 1) to determine the seasonal change of nitrate and oxalate concentration and 2) to elucidate the relationship between growth rate and the concentration of nitrate and oxalate in spinach.

\section{Materials and Methods}

Cultivars. To represent the spinach population, we collected 182 spinach cultivars currently available in Japan, considering a diverse range of responses to the photoperiods being covered. They included open-pollinated and F1 cultivars as well as cultivars from domestic strains and breeding lines. All the cultivars used are listed with respect to growth rate and source (Table 1). The growth rate of each cultivar was determined by the relative days required for harvest (RDH) to exclude seasonal variation of the actual days required for harvest (ADH). RDH was calculated to be the mean of four seasonal RDHs obtained by transforming the ADH of each growing season into the percentage of the corresponding average ADH. Then, all the 182 cultivars were categorized into one of three growth types-fast, moderate, and slow-according to the growth rate ranges of less than 95,95 to 105 , and more than 105 $\mathrm{RDH}$ respectively. These three ranges were determined on the basis of the RDH frequency distribution pattern that gave significant differences $(P<0.001)$ among their 
Table 1. Cultivars, growth rate $^{\mathrm{z}}$, and source ${ }^{\mathrm{y}}$ of seeds used in the current study.

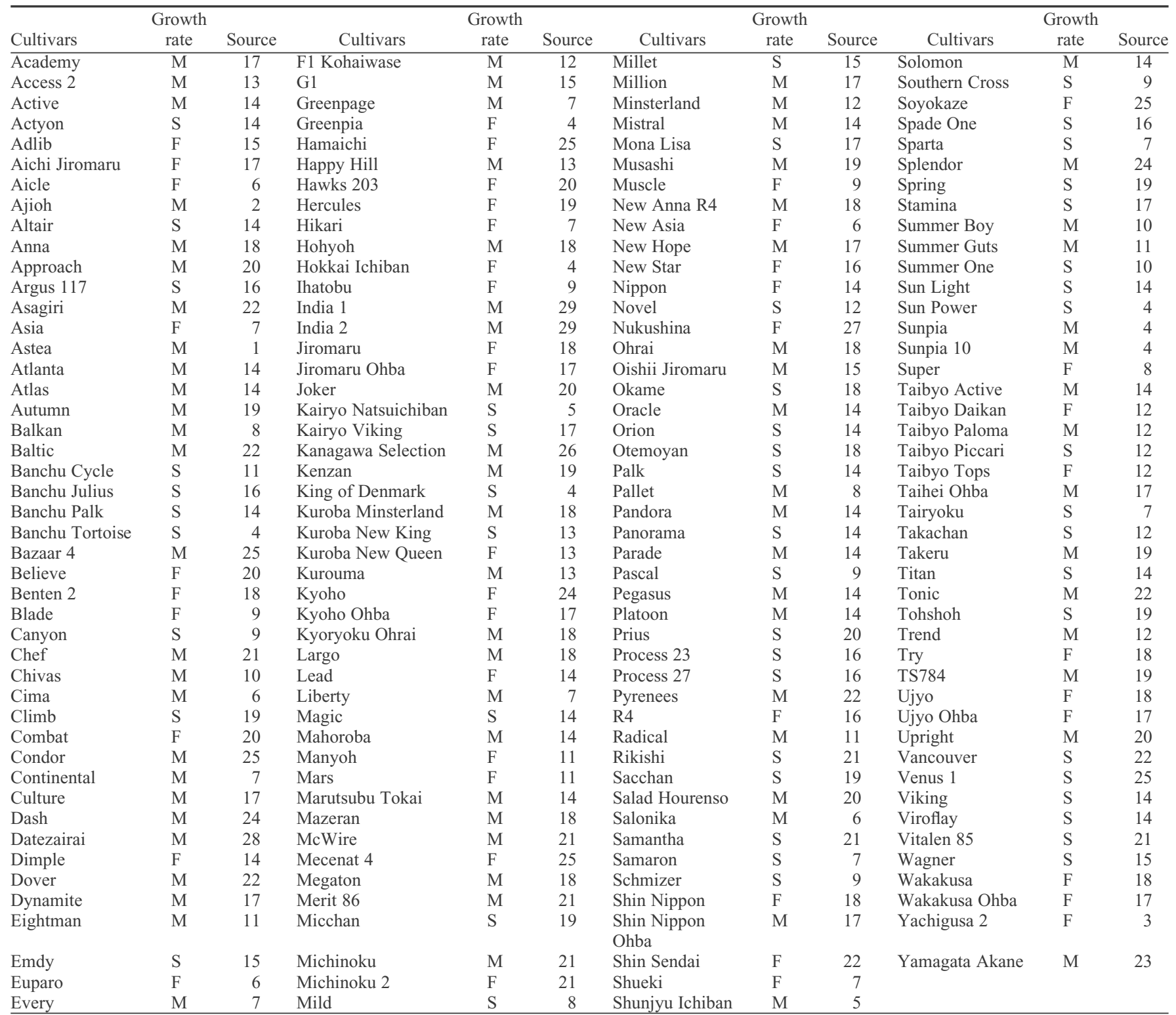

${ }^{2}$ Each cultivar was categorized into either fast $(\mathrm{F})$, moderate $(\mathrm{M})$, or slow $(\mathrm{S})$ growth types according to the relative days required from sowing to harvest (RDH). $\mathrm{RDH}$ was calculated by transforming the days required from sowing to harvest $(\mathrm{DH})$ into the percentage to the means of total $\mathrm{DH}$ in each growing season.

${ }^{y}$ 1, Asahi Industries Co. Ltd.; 2, Atariya Seed Co. Ltd.; 3, Fujii Seed Co. Ltd.; 4, Kaneko Seeds Co. Ltd.; 5, Kosaka Seed Co. Ltd.; 6, Kyowa Seed Co. Ltd.; 7 , Marutane Co. Ltd.; 8, Momose Seed Co. Ltd.; 9, Musashino Seed Co. Ltd.; 10, Nakahara Seed Co. Ltd.; 11, Nanto Seed Co. Ltd.; 12, Nitto-nosan Seed Co. Ltd.; 13, Nohara Seed Co. Ltd.; 14, Sakata Seed Co. Ltd.; 15, Sanyo Seed Co. Ltd.; 16, Snow Brand Seed Co. Ltd.; 17, Takayama Seed Co. Ltd.; 18, Takii Co. Ltd.; 19, Tohoku Seed Co. Ltd.; 20, Tokita Seed Co. Ltd.; 21, Watanabe-nohji Co. Ltd.; 22, Watanabe-saishujyo Co. Ltd.; 23, Yamagata-ken Shubyokyokai; 24, Yamatonoen Co. Ltd.; 25, Yokohamaueki Co. Ltd.; 26, Kanagawa Agricultural Technology Center; 27, 28, and 29, introduced from Hiroshima Prefecture, Hokkaido, and India respectively.

means by Welch test. The resultant fast, medium, and slow growth-type cultivars constituted $25 \%, 46 \%$, and $29 \%$ of the total cultivars respectively.

Cultivation. All the spinach cultivars were grown in the Kanagawa Agricultural Technology Center in Japan (lat. $35^{\circ} 20^{\prime} \mathrm{N}$, long. $139^{\circ} 16^{\prime} \mathrm{E}$ ) during four seasons (winter, spring, summer, and fall) to cover the growing periods over or close to the vernal equinox, summer solstice, fall equinox, and winter solstice respectively (Fig. 1A). Chronological changes of the average temperature and day length within a year at our research center are also provided (Fig. 1A). Spinach seeds were planted on 25 Oct. 2002 for winter cultivation and on 5 Mar., 7 July, and 10 Sept. 2003 for spring, summer, and fall cultivations respectively. In every cultivation, spinach plants were grown in the same size of three conventional, open-sided vinyl houses $\left(86.4 \mathrm{~m}^{2}, 5.4 \times 16 \mathrm{~m}\right)$ covered with vinyl film (thickness, $0.15 \mathrm{~mm}$ ) only on the top to avoid the effect of rainfall as shown in Fig. 1B and C. The temperature, air flow, and solar radiation inside the vinyl houses were checked and confirmed that any of these factors did not differ from the outside except that incoming solar radiation was reduced to $80 \%$ of the open field. The soil type was thick humic andosol (clay loam) with an organic matter content of $6.5 \%$ and a bulk density of
0.85 . On 30 July 2002 , just before the first winter cultivation, $200 \mathrm{~L} \cdot \mathrm{m}^{-2}$ hot water was sprayed over the soil to disinfest and make the chemical soil property uniform by washing out residual fertilizers according to the method of Kita et al. (2003). After the hot water treatment, soil $\mathrm{pH}$ was adjusted to 6.5 by applying an appropriate amount of dolomitic lime containing 5\% magnesium, and synthetic fertilizer (Kumiai complex chemical fertilizer 42 containing $14 \mathrm{~N}-6.1 \mathrm{P}-$ 11.6K; Nihonkasei Inc., Tokyo, Japan) was applied to give an $\mathrm{N}$ level of $100 \mathrm{~kg} \cdot \mathrm{ha}^{-1}$. No organic matter was amended to exclude an unpredictable $\mathrm{N}$ supply from the organic components. One day before sowing, $3 \mathrm{~L} \cdot \mathrm{m}^{-2}$ 

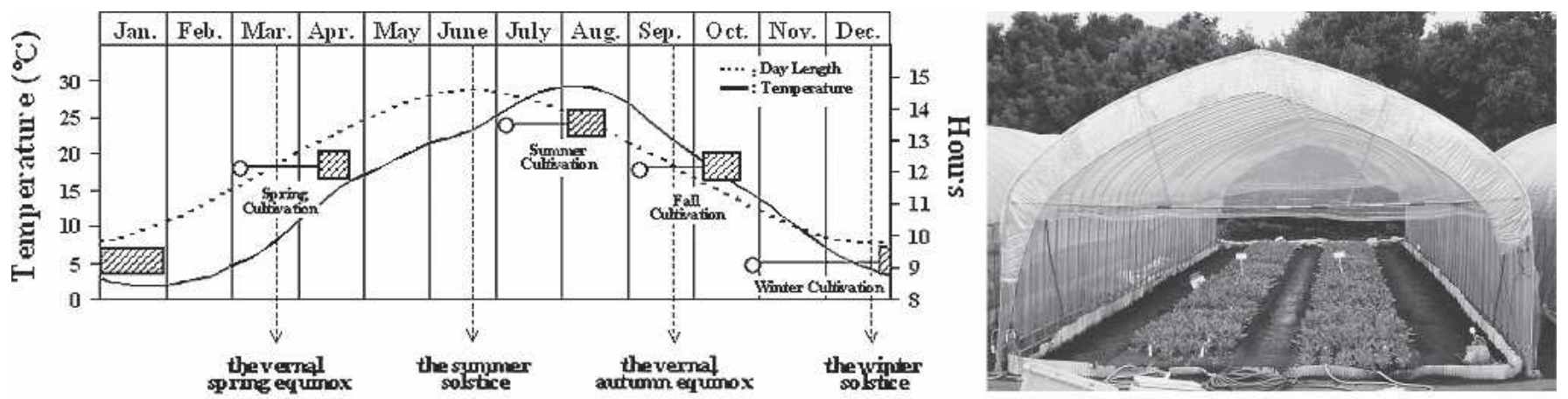

A

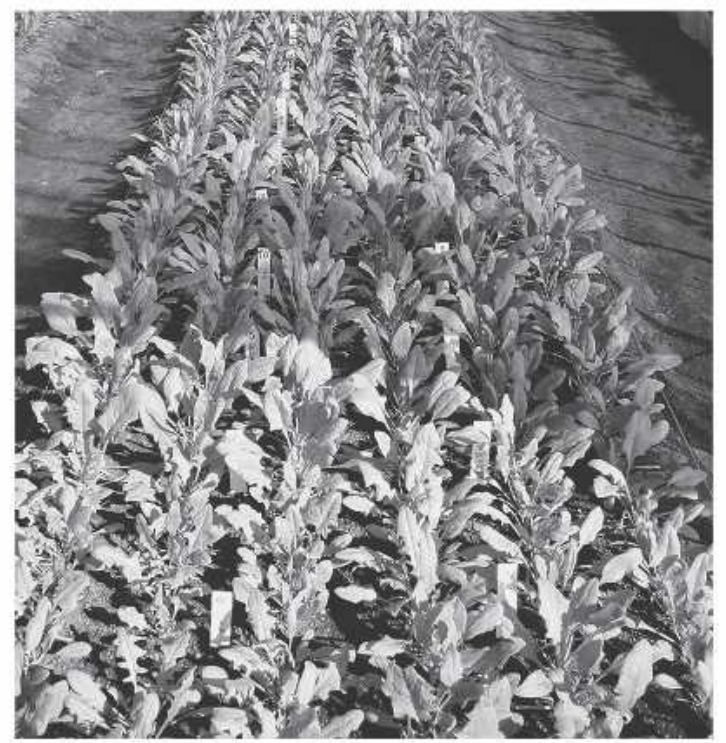

C

Fig. 1. (A-C) Schematic representation of cultivation season of spinach (Spinacia oleracea L.) in relation to the environmental factors (A), an open-sided vinyl house $\left(86.4 \mathrm{~m}^{2}, 5.4 \times 16 \mathrm{~m}\right)$ in which spinach cultivars were grown $(\mathbf{B})$, and spinach plants in the vinyl house $30 \mathrm{~d}$ after sowing $(\mathbf{C})$ in the fall cultivation in 2003. In A, open circles and hatched rectangles represent the sowing date and the harvesting period respectively. Solid and dotted lines represent the average temperature and the day length respectively. Spinach cultivation took place from 25 Oct. 2002 to 24 Oct. 2003 at Kanagawa Agricultural Technology Center, Hiratsuka, Kanagawa, Japan, at latitude $35^{\circ} 20^{\prime} \mathrm{N}$ and longitude $139^{\circ} 16^{\prime} \mathrm{E}$.

water was applied to the soil for uniform soil moisture. Spinach seeds were pregerminated by immersing them in running tap water for $24 \mathrm{~h}$, wrapping them with filter paper, and keeping them in a refrigerator at $4{ }^{\circ} \mathrm{C}$ for 2 to 3 d. Three germinated seeds were sown per each drill at a $5-\mathrm{cm}$ distance in six rows $15 \mathrm{~cm}$ apart on a $120-\mathrm{cm}$-wide raised bed at a height of $20 \mathrm{~cm}$, followed by an application of $3 \mathrm{~L} \cdot \mathrm{m}^{-2}$ of water. For each cultivar, one plot consisted of 21 plants of three rows with seven plants $\left(0.21 \mathrm{~m}^{2}\right)$, and three plots were prepared using the same size in three vinyl houses to give three replications with triplicates. Plots were randomly arranged within a vinyl house. After germination, when the first true leaves emerged, seedlings were thinned to one plant per each drill. Water (3 $\mathrm{L} \cdot \mathrm{m}^{-2}$ ) was applied as necessary until harvest.

Harvest and sampling. When more than $50 \%$ of the plants in each plot grew to $\approx 25$ $\mathrm{cm}$ of the height, which is the standard market size in Japan, one plant that grew to an average size was randomly selected from each row to obtain three plants per plot, totaling nine plants per cultivar. Bolting plants that had more than $1 \mathrm{~cm}$ in stalk length were excluded for sampling. In the case of winter cultivation, several cultivars that grew extremely slow such as 'Novel', 'Viking', and 'Viroflay', were harvested 95 d after sowing even though they were less than $25 \mathrm{~cm}$. Plants were harvested for sampling in the morning from 9:00 to 10:00 Am by cutting at the top of hypocotyls. After total weight, length of petiole, and length of leaf blade of the largest leaf were measured, and three plants were put in a plastic bag together and immediately frozen at $-20{ }^{\circ} \mathrm{C}$.

Determination of nitrate and oxalate concentration. Nitrate and oxalate concentrations were determined on a fresh weight basis by one-step analysis with high-performance liquid chromatography (HPLC). Three frozen spinach plants per one plot were directly homogenized together with deionized water of $10 \times$ volume to the fresh weight for $5 \mathrm{~min}$ at room temperature and the homogenates were immediately filtered through filtrate paper (ADVANTEC no. 3; Advantec, Tokyo) on ice. The filtrates were further filtered using the spin column Ultra-
free-MC 0.45- $\mu \mathrm{m}$ PTFE membrane (Millipore, Billerica, Mass.) and centrifuged at $5000 \times g_{\text {n }}$ for $60 \mathrm{~min}$ at $4{ }^{\circ} \mathrm{C}$; the samples were then stored at $-20^{\circ} \mathrm{C}$. Just before HPLC analysis, frozen filtrates were thawed on ice, diluted to $10 \times$ with deionized water, and transferred to a disposable vial ( $\mathrm{S} / \mathrm{T}$ micro vial; Tomsic, Tokyo). HPLC analysis was performed using the Mightysil RP- $\mathrm{C}_{18}$ Aqua column (column size of $250 \mathrm{~mm}$ in length with diameter of $4.6 \mathrm{~mm}$, particle size of $5 \mu \mathrm{m}$, Kanto Chemical, Tokyo) in the LC-10A system (Shimadzu, Kyoto, Japan) with $5 \mathrm{~mm}$ tetrabutyl ammonium chloride in phosphate ammonium buffer $(\mathrm{pH}$, 6.8) for dissociate solvent, at a speed of 1.0 $\mathrm{mL} \cdot \mathrm{min}^{-1}$ with the column temperature at 30 ${ }^{\circ} \mathrm{C}$, and detected at $210 \mathrm{~nm}$. Results were expressed as milligram per kilogram fresh weight of $\mathrm{NO}_{3}$ or oxalate. Data were subjected to statistical analysis using JUSE-StatWorks version 4.0 (The Japanese Union of Scientists \& Engineers Inc., Tokyo). Nonparametric methods such as the Welch test and the Kruskal-Wallis test were used when the homogeneity of variances assumption of analysis of variance was not satisfied. 


\section{Results and Discussion}

Growth of spinach. In the current study, we performed a series of experiments to reveal seasonal changes in nitrate and oxalate concentration. We then analyzed the relationships in relation to the growth rate of spinach cultivars (Table 1) grown over four consecutive seasons under one soil N level (100 kg$\mathrm{N} \cdot \mathrm{ha}^{-1}$ ). Seasonal changes in environmental conditions allowed us to investigate the effects of temperature, day length, and light intensity on spinach growth (Fig. 1A) (Cantliffe, 1972a,b,c). Growing temperatures were low in the spring and higher in the fall, even though day length $(12 \mathrm{~h})$ and light intensity are similar between the two seasons. Temperature and light intensity were higher during the long days of summer and lower during the short days of the winter season (Table 2). Each spinach cultivar showed different growth characteristics depending on its unique response to photoperiod and temperature. The difference of average days required for harvest (AveDHs) among the growing seasons was significant and negatively correlated, yet not statistically significant, with the average temperature. In winter cultivation, AveDHs exceeded $85 \mathrm{~d}$ whereas summer and fall cultivation needed only 33 to $35 \mathrm{~d}$ (Table 2). Spring cultivation required 10 $\mathrm{d}$ more than fall cultivation, which reflected the difference of average temperature between the two growing periods, although photoperiods between the two seasons were similar.

Seasonal change in nitrate concentration. Average nitrate concentration of the 182 spinach cultivars in the spring, summer, and fall cultivation seasons was 4100 to 4300 $\mathrm{mg} \cdot \mathrm{kg}^{-1}$ fresh weight and was not significantly different from each other whereas nitrate level during the winter season was $3800 \mathrm{mg} \cdot \mathrm{kg}^{-1}$ fresh weight, which was significantly lower $(P<0.01)$ than the other three seasons (Table 2). Chung et al. (2003) reported the nitrate concentration of winter and summer cultivated spinach in Korea to be $4259 \mathrm{mg} \cdot \mathrm{kg}^{-1}$ fresh weight, which is consistent with data in the current study. These results suggest that nitrate concentrations of overall spinach cultivars are almost the same level when compared under the same $\mathrm{N}$ application rate regardless of the growing season, except in the winter cultivation season, which also increases AveDH.

Frequency distribution profiles of nitrate concentrations (at the interval of $500 \mathrm{mg} \cdot \mathrm{kg}^{-1}$ fresh weight) for each cultivation season revealed grouping of cultivars into two distinct patterns: narrow in spring and fall, and broad in winter and summer (Fig. 2). In the spring and fall cultivations, $34.4 \%$ and $41.8 \%$ of the total cultivars fell into the mode range of 4000 to $4500 \mathrm{mg} \cdot \mathrm{kg}^{-1}$ fresh weight and 4500 to $5000 \mathrm{mg} \cdot \mathrm{kg}^{-1}$ fresh weight respectively. Winter and summer cultivation, on the contrary, showed significantly broader distribution profiles, ranging from 1200 to over $8000 \mathrm{mg} \cdot \mathrm{kg}^{-1}$ fresh weight. Temperature and light intensity are important environmental
Table 2. Environmental conditions and measurement factors of each cultivation season of 182 spinach cultivars used.

\begin{tabular}{|c|c|c|c|c|}
\hline \multirow{3}{*}{$\begin{array}{l}\text { Environmental conditions } \\
\text { and measurement factors }\end{array}$} & \multicolumn{4}{|c|}{ Cultivation season ${ }^{z, y}$} \\
\hline & Winter & Spring & Summer & Fall \\
\hline & Oct.-Jan. & Mar.-Apr. & July-Aug. & Sept.-Oct. \\
\hline Average temperature $\left({ }^{\circ} \mathrm{C}\right)$ & 6.8 & 9.7 & 23.5 & 19.9 \\
\hline Average day length & $10 \mathrm{~h} 12 \mathrm{~min}$ & $12 \mathrm{~h} 22 \mathrm{~min}$ & $14 \mathrm{~h} 5 \mathrm{~min}$ & $11 \mathrm{~h} 54 \mathrm{~min}$ \\
\hline Days required for harvest & $85.7 \pm 0.6 \mathrm{~d}$ & $45.7 \pm 0.3 \mathrm{c}$ & $32.7 \pm 0.2 \mathrm{a}$ & $35.5 \pm 0.1 \mathrm{~b}$ \\
\hline $\begin{array}{l}\text { Nitrate concn }\left(\mathrm{mg} \cdot \mathrm{kg}^{-1}\right. \\
\text { fresh weight) }\end{array}$ & $3797 \pm 103 \mathrm{a}$ & $4165 \pm 38 b$ & $4328 \pm 96 b$ & $4122 \pm 44 b$ \\
\hline $\begin{array}{l}\text { Oxalate concn }\left(\mathrm{mg} \cdot \mathrm{kg}^{-1}\right. \\
\text { fresh weight) }\end{array}$ & $10929 \pm 132 \mathrm{~d}$ & $8903 \pm 60 \mathrm{c}$ & $7525 \pm 80 \mathrm{~b}$ & $6149 \pm 79 a$ \\
\hline
\end{tabular}

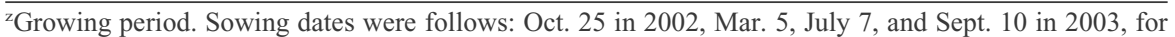
winter, spring, summer and fall cultivation, respectively.

${ }^{y}$ Each value is the mean $\pm \mathrm{SE}$ of all the cultivars used. Values within a row with different letters are significantly different $(P<0.01)$ according to Welch's test.
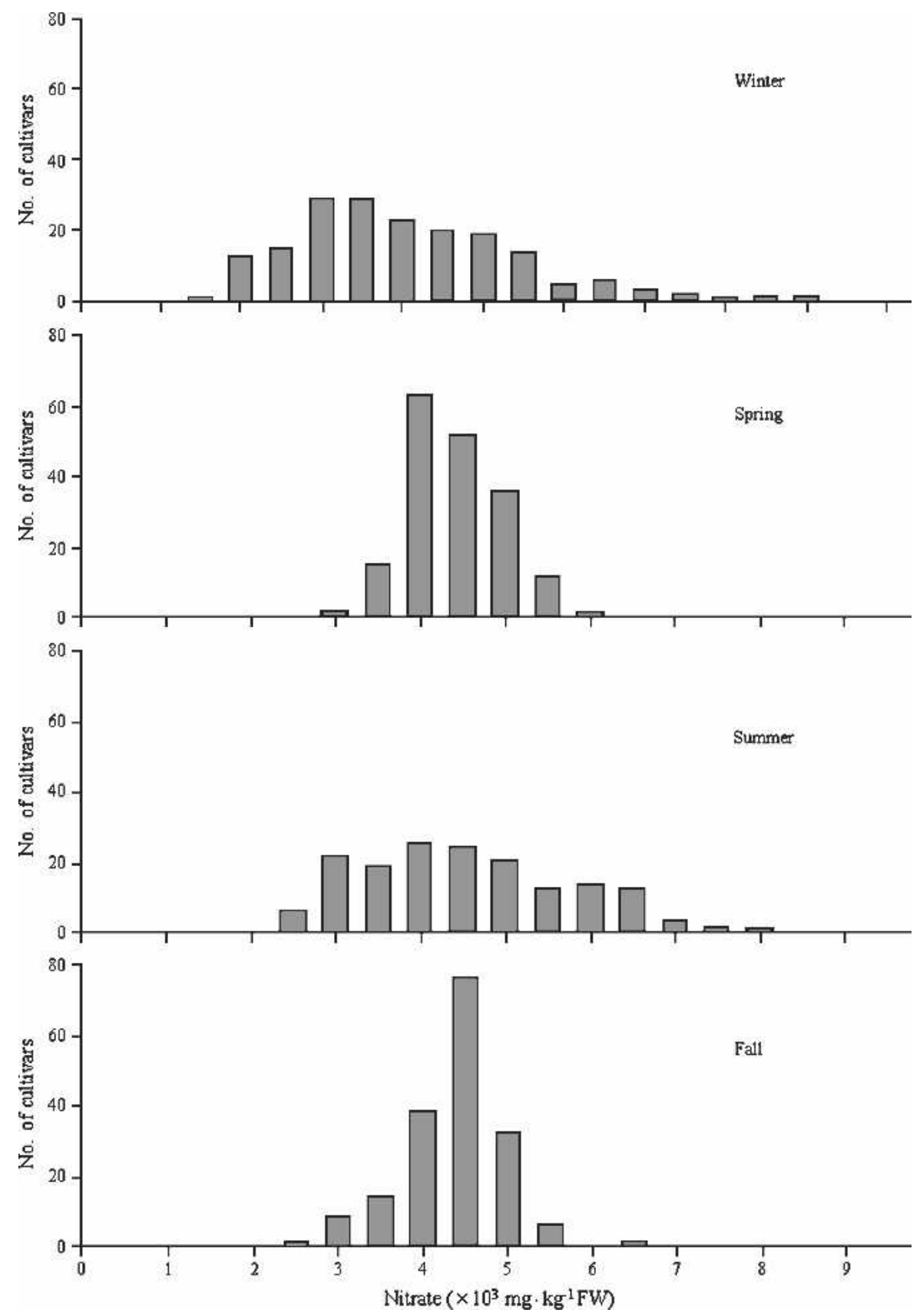

Fig. 2. Frequency distribution of nitrate concentration of 182 spinach (Spinacia oleracea L.) cultivars at the $500-\mathrm{mg} \cdot \mathrm{kg}^{-1}$ fresh weight interval in the winter, spring, summer, and fall cultivations from Oct. 2002 to Oct. 2003. Sowing dates are follows: 25 Oct. 2002, 5 Mar. 2003, 7 July 2003, and 10 Sept. 2003 for the winter, spring, summer, and fall cultivations respectively. 
factors that can influence the nitrate metabolism of spinach (Breimer, 1982; Elia et al., 1998; Maynard et al., 1976; Muramoto, 1999). It is reasonable that the frequency distribution patterns of nitrate concentration differ greatly within a cultivation season, especially in winter and summer, when the environmental conditions are unfavorable for their growth.

The lower nitrate levels observed in the winter cultivation might have resulted from the low average temperature and light intensity that reduced nitrate reductase activity and root activity from absorbing nitrate from the soil (Cantliffe, 1972a; Kojima et al., 1995; Olday et al., 1976). However, there were several cultivars in the current study such as 'R4', 'Yachigusa 2', 'Access 2', and 'Cima' that had a nitrate concentration in the winter that was 1.5 times higher than the other seasons. These results may point to a genetic influence for nitrate absorption, turnover, and assimilation of absorbed nitrate in spinach (Cantliffe, 1972a,b).

Seasonal change of oxalate concentration. Unlike nitrate concentration, average oxalate concentration of all 182 spinach cultivars significantly varied depending on the cultivation season, being highest in winter $(10,929$ $\mathrm{mg} \cdot \mathrm{kg}^{-1}$ fresh weight) and lowest in fall (6149 $\mathrm{mg} \cdot \mathrm{kg}^{-1}$ fresh weight; Table 2). In addition, the average oxalate concentration of the four growing seasons positively correlated with AveDHs $(r=0.908, P<0.01)$, indicating that the longer the growing period, the higher the oxalate concentration. Frequency distribution profiles of oxalate concentration (depicted at the $500-\mathrm{mg} \cdot \mathrm{kg}^{-1}$ fresh weight interval) revealed distinct seasonal difference among the growing seasons (Fig. 3). The spring cultivation showed the narrowest distribution profile at $9000 \mathrm{mg} \cdot \mathrm{kg}^{-1}$ fresh weight, and the summer and fall cultivations represented relatively broad but similar distribution patterns at $7500 \mathrm{mg} \cdot \mathrm{kg}^{-1}$ fresh weight and $6500 \mathrm{mg} \cdot \mathrm{kg}^{-1}$ fresh weight respectively. In winter, the distribution profile was so broad that it was difficult to specify the mode value, probably because of the extremely long growing period.

Because oxalate is one of the final products of plant carbohydrate metabolism and because it accumulates in the vacuole (Raven and Smith, 1976), it is conceivable that the amount of oxalate within a cell would increase in accordance with plant age. The results obtained showed that oxalate concentration is closely associated with the length of the spinach growing period: low in the short growing period and high in the long growing period. Therefore, it is possible that plant growth rate, and thus the plant age, primarily account for the level of oxalate accumulated in the plant tissue.

Relationship among $R D H$, nitrate, and oxalate concentrations. Relationship among $\mathrm{RDH}$ and nitrate and oxalate concentrations were further analyzed by using the relative values to exclude the seasonal variations. Relative values of nitrate and oxalate were calculated in the same way as RDH and thus represented the percentage of the mean of the
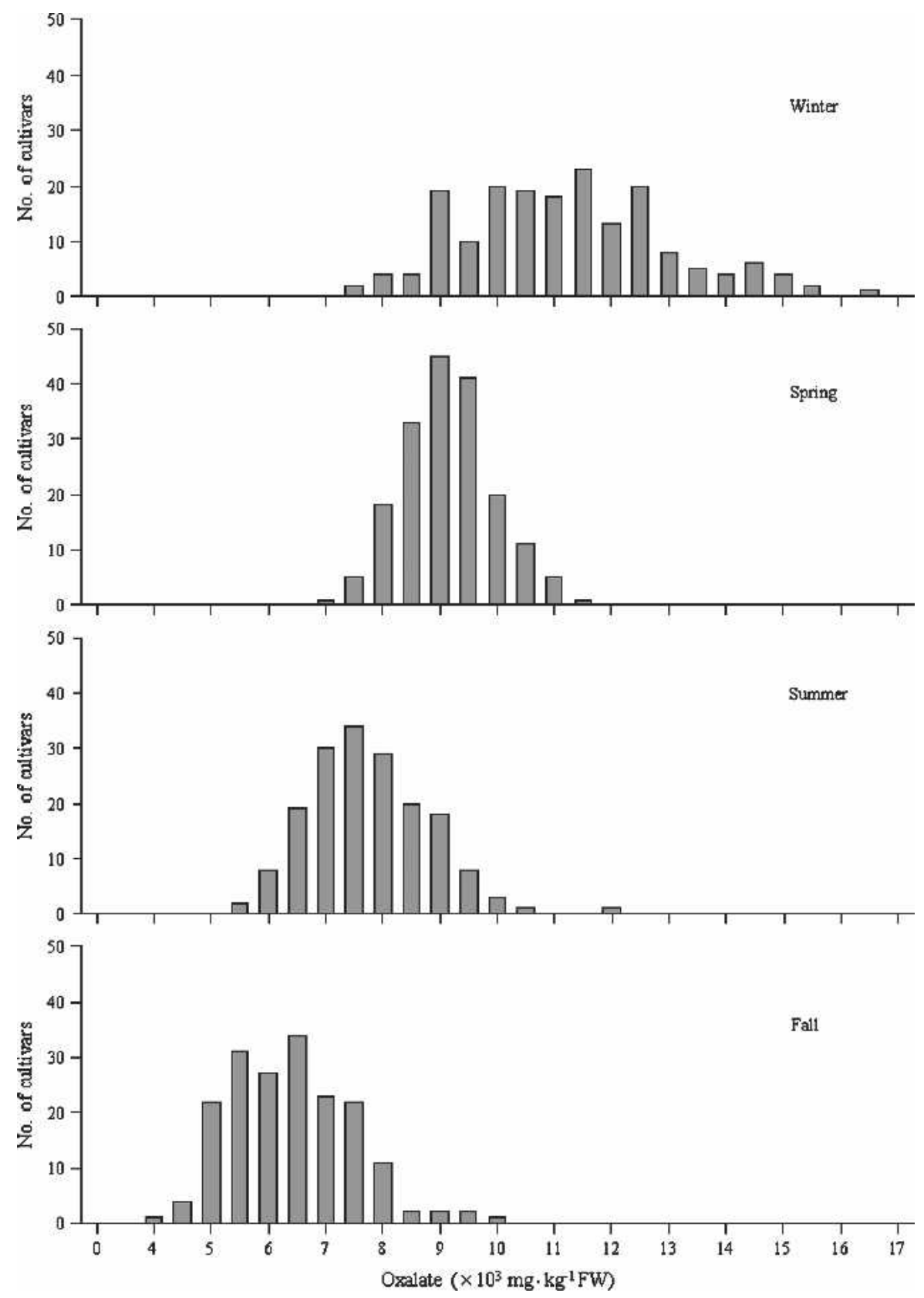

Fig. 3. Frequency distribution of oxalate concentration of 182 spinach (Spinacia oleracea L.) cultivars at the $500-\mathrm{mg} \cdot \mathrm{kg}^{-1}$ fresh weight interval in the winter, spring, summer, and fall cultivations from Oct. 2002 to Oct. 2003. Sowing dates are follows: 25 Oct. in 2002, 5 Mar. 2003, 7 July 2003, and 10 Sept. 2003 for the winter, spring, summer, and fall cultivations respectively.

four seasonal relative values. When the relative nitrate and oxalate concentrations were plotted respectively against $\mathrm{RDH}$, relative nitrate concentration showed a moderate negative correlation with RDH $(r=0.411$, $P<0.001$; Fig. 4A), whereas the relative oxalate concentration showed a strong positive correlation with $\mathrm{RDH}(r=0.566$, $P<0.001$; Fig. 4B). The results clearly indicate that the growth rate primarily accounts for nitrate and oxalate concentration.

As for the relationship between nitrate and oxalate concentrations, Spearman's rank correlation was applied because the variances of the relative nitrate and oxalate concentrations were not homogeneous. We used average ranks of nitrate and oxalate concentration of a spinach cultivar calculated as the mean of the four seasonal ranks from the lowest to the highest. As expected, a moderate negative correlation $(r=0.325, P<0.001)$ was detected between nitrate and oxalate concentrations (Fig. 4C), which confirmed our earlier results. Tanaka et al. (2001) suggested by a tracer study of oxalate synthesis and nitrate reduction that the main function of oxalate in spinach is neutralization of $\mathrm{OH}^{-}$released during nitrate reduction, leading to the alkalization of cytosol $\mathrm{pH}$. Therefore, the results obtained in the current study suggest that, in spinach, nitrate and oxalate might play a counterrole to each other. 
Growth type analysis of nitrate and oxalate concentration. To confirm the relationship between the growth rate of spinach cultivars and their nitrate and oxalate concentrations, RDHs, seasonal nitrate and oxalate concentrations, and bolting rates were analyzed on the basis of three growth types (Table 3). Relative days to harvest of the three growth types were distinct from each other and represented values expected from the range that categorized the cultivars into fast, moderate, and slow. The Welch test was applied as a nonparametric statistical analysis method to detect the significance because the variances of the means were not homogeneous within the same growth types (row) among the four seasons. As a result, nitrate concentrations of fast-growing cultivars such as 'Jiromaru Ohba', 'Ujyo Ohba', and 'Wakakusa Ohba' were significantly higher in the fall $(P<0.05)$, winter, and summer $(P<0.01)$ than those of slow-growing cultivars such as 'Micchan', 'Rikishi', and 'Takachan'. Moderategrowing cultivars such as 'Chivas', 'Datezairai', and 'Mazeran' generally showed the intermediate levels of nitrate. Within the same growth types, the seasonal nitrate concentration was significantly different only in slowgrowing cultivars $(P<0.01)$ as a result of the relatively high levels of nitrate concentration in spring. This relationship essentially coincided with the results obtained by the overall analysis (Table 2). On the contrary, oxalate concentration was the highest in slow-growing cultivars such as 'Canyon', 'Kuroba New King', and 'Millet', and was the lowest in fast-growing cultivars such as 'Ujyo Ohba', 'Kyoho Ohba', and 'Nukushina', along with the four growing seasons. The differences were significant among the three growth types in winter and fall $(P<0.01)$ and between the fast and others in spring $(P<$ 0.01 or 0.05 ) but not in summer. However, within the same growing seasons (column) in which the means were normally distributed and have homogeneous variances, oxalate concentration significantly differed $(P<$ 0.01 by LSD) among the four seasons, as in the overall analysis (Table 2). Bolting rates negatively correlated with the RDHs ( $r=$ $0.989, P<0.01$ ), reflecting the growth speed of spinach cultivars. Together, these results confirmed that fast-growing cultivars contain higher nitrate and lower oxalate whereas slow-growing cultivars contain lower nitrate and higher oxalate when compared under the same nitrogen application rat.

\section{Conclusion}

The results obtained in the current study demonstrate that under the same $\mathrm{N}$ application rate, overall nitrate level in spinach cultivars is basically constant regardless of the growing season, except in the winter cultivation, which showed a statistically lower nitrate concentration, whereas the oxalate level greatly fluctuated depending on the growing season. The results also show that the growth rate of spinach cultivars primarily accounts for the nitrate and oxalate concentration. Fast-growing cultivars contain high nitrate but low oxalate, whereas slow-growing cultivars contain low nitrate but high oxalate, regardless of the growing season. As the growth rate of spinach depends mostly on temperature, it is natural that the seasonal fluctuation of oxalate resulted from the seasonal variation in the growth rate of spinach. A converse relationship between nitrate and oxalate concentration within a spinach plant suggests that nitrate and oxalate might play a counterrole to each other in maintaining spinach metabolism homeostatic. Our results can be applied for the breeding of low-oxalate content spinach cultivars by using fast-growing cultivars. Although the nitrate concentration in spinach was shown to be higher in the fast-growing cultivars, various cultivation practices that can reduce the nitrate concentration in spinach, such as preplant soil nitrate testing to reduce the nitrate application levels and compost-based fertility management (Breimer, 1982; Muramoto, 1999), have been developed. Therefore, it may be possible to
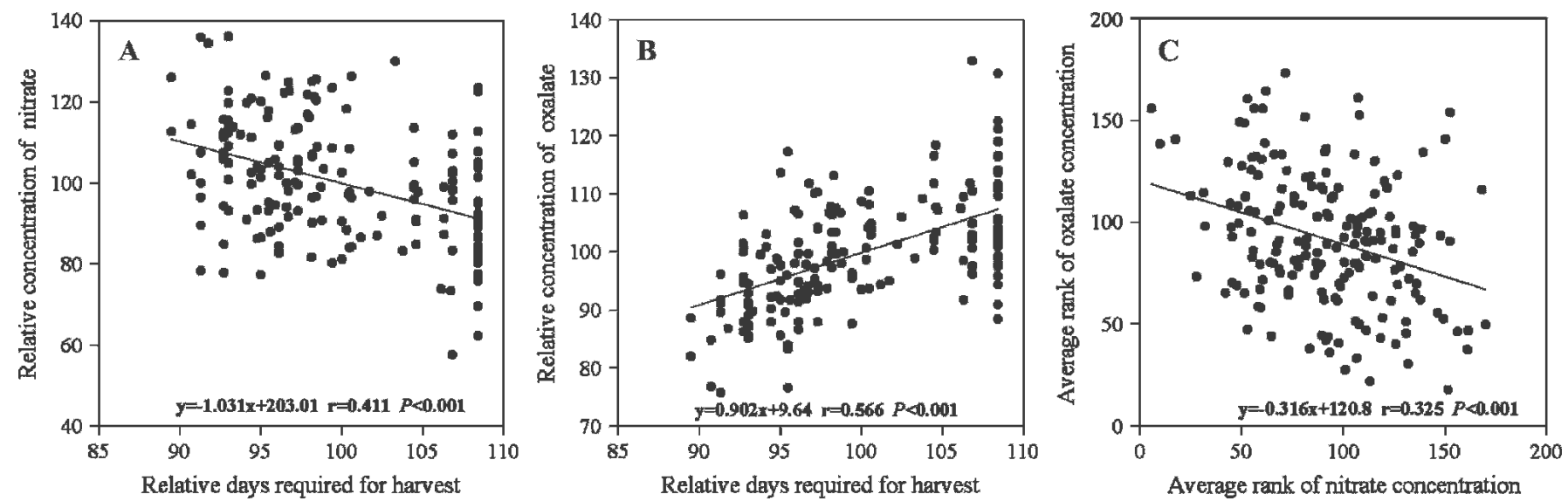

Fig. 4. (A-C) Correlation between relative days required for harvest ( $\mathrm{RDH})$ and relative nitrate concentration (A), RDH and relative oxalate concentration (B), and average rank of nitrate and oxalate concentrations $(\mathbf{C})$. Each dot represents the value of a spinach cultivar. Pearson's correlation was applied to A and $\mathbf{B}$, and Spearman's rank correlation was applied to $\mathbf{C}$. In $\mathbf{A}$ and $\mathbf{B}, \mathrm{RDH}$ represents the mean of four seasonal RDHs calculated by transforming the actual days required for harvest into the percentage of the corresponding seasonal RDH of each growing season. Relative nitrate and oxalate concentrations were calculated in the same way with RDH. In $\mathbf{C}$, the average rank of nitrate and oxalate concentrations of a spinach cultivar was calculated as the mean of the four seasonal ranks from the lowest to the highest.

Table 3. Relative days required from sowing to harvest, seasonal nitrate and oxalate concentrations, and bolting rate of fast-, moderate-, and slow-growing cultivars.

\begin{tabular}{|c|c|c|c|c|c|c|c|c|c|c|c|c|c|c|}
\hline \multirow{3}{*}{$\begin{array}{l}\text { Growth } \\
\text { rate }^{\mathrm{z}} \text { of } \\
\text { cultivars }\end{array}$} & \multirow{3}{*}{$\begin{array}{l}\text { Relative } \\
\text { days until } \\
\text { harvest }^{z}\end{array}$} & \multicolumn{4}{|c|}{ Nitrate concn (mg. $\mathrm{kg}^{-1}$ fresh weight) } & & \multicolumn{4}{|c|}{ Oxalate concn (mg. $\mathrm{kg}^{-1}$ fresh weight) } & & \multicolumn{2}{|c|}{ Bolting rate $(\%)$} & \\
\hline & & Winter & Spring & Summer & Fall $^{2}$ & & Winter & Spring & Summer & Fall & & Spring & Summer & \\
\hline & & Oct.-Jan. & Mar.-Apr. & July-Aug. & Sept.-Oct. & & Oct.-Jan. & Mar.-Apr. & July-Aug. & Sept.-Oct. & & Mar.-Apr. & July-Aug. & \\
\hline Fast & $93.0 \mathrm{~A}$ & $4190 \mathrm{~B}$ & $4187 \mathrm{~A}$ & $4683 \mathrm{~B}$ & $4424 \mathrm{C}$ & $\mathrm{NS}^{\mathrm{y}}$ & $9942 \mathrm{~A}$ & $8567 \mathrm{~A}$ & $7379 \mathrm{~A}$ & $5261 \mathrm{~A}$ & $* *$ & $1.3 \mathrm{C}$ & $70.1 \mathrm{C}$ & $* *$ \\
\hline Slow & $107.9 \mathrm{~B}$ & $3175 \mathrm{~A}$ & $4163 \mathrm{~A}$ & 3985 A & $3684 \mathrm{~A}$ & $* *$ & $11755 \mathrm{C}$ & 8948 b & $7348 \mathrm{~A}$ & $7140 \mathrm{C}$ & $* *$ & $0 \mathrm{~A}$ & $13.6 \mathrm{~A}$ & ** \\
\hline
\end{tabular}

${ }^{2}$ For details, see the footnote in Table 1.

yValues within a column with different letters are significantly different (uppercase letter, $P<0.01$; lowercase letter, $P<0.05$ ) according to Fisher's least significant test. Values within a row with NS and ** represent not significant and significant at $P<0.01$ respectively by Kruskal-Wallis test for nitrate and oxalate concentrations and by the Welch test for bolting rate. 
reduce the nitrate and oxalate concentration of spinach at the same time, for example, by using fast-growing cultivars in combination with reduced soil nitrate application level and organic-based composts.

\section{Literature Cited}

Barker, A.V. 1975. Organic vs. inorganic nutrition and horticultural crop quality. HortScience 10:50-53.

Barker, A.V., D.N. Maynard, and H.A. Mills. 1974. Variations in nitrate accumulation among spinach cultivars. J. Amer. Soc. Hort. Sci. 99:132-134.

Breimer, T. 1982. Environmental factors and cultural measures affecting the nitrate concentration in spinach. Fertilizer Res. 3:191-292.

Cantliffe, D.J. 1972a. Nitrate accumulation in spinach grown under different light intensities. J. Amer. Soc. Hort. Sci. 97:152-154.

Cantliffe, D.J. 1972b. Nitrate accumulation in vegetable crops as affected by photoperiod and light duration. J. Amer. Soc. Hort. Sci. 97:414-418.

Cantliffe, D.J. 1972c. Nitrate accumulation in spinach grown at different temperatures. J. Amer. Soc. Hort. Sci. 97:674-676.

Cantliffe, D.J. 1973. Nitrate accumulation in table beets and spinach as affected by nitrogen, phosphorus, and potassium nutrition and light intensity. Agron. J. 65:563-565.

Chung, S.Y., J.S. Kim, M. Kim, M.K. Hong, J.O. Lee, C.M. Kim, and I.S. Song. 2003. Survey of nitrate and nitrite contents of vegetables grown in Korea. Food Addit. Contam. 20:621-628.

Elia, A., P. Santamaria, and F. Serio. 1998. Nitrogen nutrition, yield and quality of spinach. J. Sci. Food Agr. 76:341-346.

Food and Agriculture Organization. 2005 FAO STAT database. 22 July 2006. http://faostat. fao.org.
Gangolli, S.D., P.A. van den Brandt, V.J. Feron, C. Janzowsky, J.H. Koeman, G.J. Speijers, B. Spiegelhalder, R. Walker, and J.S. Wishnok. 1994. Nitrate, nitrite and $\mathrm{N}$-nitroso compounds. Eur. J. Pharmacol. 291:1-38.

Kita, N., K. Nishi, and S. Uematsu. 2003. Hot water treatment as a promising alternative to methyl bromide. Proc. Intl. Res. Conf. Methyl Bromide Alternatives and Emissions Reductions. 5 Aug. 2006. http://www.mbao.org/

Kojima, M., S.-J. Wu, H. Fukui, T. Sugimoto, T. Nanmori, and Y. Oji. 1995. Phosphorylation dephosphorylation of Komatsuna (Brassica campestris) leaf nitrate reductase in vivo and in vitro in response to environmental light conditions: Effects of protein kinase and protein phosphatase inhibitors. Physiol. Planta. 93:139-145.

Libert, B. and V.R. Franceschi. 1987. Oxalate in crop plants. J. Agr. Food Chem. 35:926-938.

Lorenz, O.A. 1978. Potential nitrate levels in edible plant parts, p. 201-219. In: D.R. Nielsen, and J.G. MacDonald (eds.). Nitrogen in the environment. Academic Press, New York.

Massey, L.K., H. Roman-Smith, and R.A. Sutton. 1993. Effect of dietary oxalate and calcium on urinary oxalate and risk of formation of calcium oxalate kidney stones. J. Amer. Diet. Assoc. 93:901-906.

Maynard, D.N., A.V. Barker, P.L. Minotti, and N.H. Peck. 1976. Nitrate accumulation in vegetables. Adv. Agron. 28:71-118.

Muramoto, J. 1999. Comparison of nitrate content in leafy vegetables from organic and conventional farms in Calif. Organic Farming Res. Foundation, Santa Cruz, CA. 5 Aug. 2006 http://www.agroecology.org/people/joji/research/ nitrate.htm

Olday, F.C., A.V. Barker, and D.N. Maynard. 1976. A physiological basis for different patterns of nitrate accumulation in two spinach cultivars. J. Amer. Sci. Hort. Sci. 101:217-219.

Pandy, S.C. and G. Kalloo. 1993. Spinach Spinacia oleracea L., 325-336. In: G. Kalloo, and B.O. Bergh (eds.). Genetic improvement of vegetable crops. Pergamon Press, Oxford. UK.

Raven, J.A. and F.A. Smith. 1976. Nitrogen assimilation and transport in vascular land plants in relation to intracellular $\mathrm{pH}$ regulation. New Phytol. 76:415-431.

Regan, W.S., V.N. Lambeth, J.R. Brown, and D.G. Blevins. 1968. Fertilization interrelationships in yield, nitrate and oxalic acid content of spinach. J. Amer. Soc. Hort. Sci. 93:485492.

Tanaka, F., T.H. Kim, and T. Yoneyama. 2001 Relationship between oxalate synthesis and nitrate reduction in spinach (Spinacia oleracea L.) plants tracing by ${ }^{13} \mathrm{C}$ and ${ }^{15} \mathrm{~N}$, p. $302-303$. In: W.W.J. Horst, M.K. Schenk, A. Bürkert, N. Claassen, H. Flessa, W.B. Frommer, H.E. Goldbach, H.-W. Olfs, V. Römheld, B. Sattelmacher, U. Schmidhalter, S. Schubert, N. von Wirén, and L. Wittenmayer (eds.). Plant nutrition: Food security and sustainability of agro-ecosystems. XIV Intl. Plant Nutr. Colloq. Kluwer Academic Publishers, the Netherlands.

Walker, R. 1990. Nitrates, nitrites and N-nitroso compounds: A review of the occurrence in food and diet and the toxicological implications. Food Addit. Contam. 7:717-768.

World Health Organization. 1995. Evaluation of certain food additives and contaminants, p. 2935. Forty-fourth report of the Joint FAO/WHO Expert Committee on Food Additives. WHO tech. rept. ser. no. 859. Geneva, Switzerland. 5 Aug. 2006. http://www.who.int/ipcs/publications/ jecfa/reports/en/. 